International Journal of Social Science And Human Research

ISSN(print): 2644-0679, ISSN(online): 2644-0695

Volume 05 Issue 01 January 2022

DOI: $10.47191 / \mathrm{ijsshr} / \mathrm{v} 5-\mathrm{i} 1-43$, Impact factor-5.586

Page No: 315-323

\title{
Juridical Analysis of the Development of Copyright Law in Relation to Legal Purposes
}

\author{
Dedi Riyanto ${ }^{1}$, Kholis Roisah ${ }^{2}$ \\ ${ }^{1}$ Head of Civil and Administrative Section of the Civil Service Section at the Batang District Prosecutor's Office \\ ${ }^{2}$ Faculty of Law, Diponegoro University
}

\begin{abstract}
Introduction to the Problem: One example of regulations in the economic field is Intellectual Property Rights (IPR). The Copyright Law has been amended many times, even within a period of approximately twenty years, the relevant law has changed four times. The purpose of the law is justice, legal certainty and expediency, thus giving the desire to review the Copyright Law to be able to realize the legal objectives.

Objectives/Study Objectives: This paper aims to determine the Juridical Analysis of the Development of Copyright Law in Relation to Legal Objectives

Design/Methodology/Approach: This paper is included in the type of normative legal research which provides a prescriptive on Juridical Analysis of the Development of Copyright Law in Relation to Legal Objectives. The technique of collecting legal materials is carried out by studying literature to collect legal materials by reading laws and regulations, official documents and literature related to problems that must be carried out by the author. The legal material analysis technique is carried out qualitatively

Findings: The results show that, the purpose of the law is as a social engineering tool, so that the Intellectual Property Rights Act is also a social engineering tool aimed at making people obey the law in the direction of a law-abiding society in the field of IPR is not yet optimal. The development of the Copyright Law in law with legal objectives can be seen from the legal substance, legal structure, and Indonesian culture.
\end{abstract}

Paper Type: Research Article

KEYWORDS: Copyright Law; Justice; Certainty; Benefits

\section{INTRODUCTION}

The process of developing the Copyright Law, either voluntarily or by force, has reflected that the Indonesian state is optimally trying to protect public and private interests by enacting the Copyright Law and its amendments accompanied by sanctions as a preventive measure. As well as repressive measures to prevent and overcome copyright infringement that can harm the creator and the state. However, this change in law should be directed at the creation of a legal system that allows the people's basic rights to be respected, fulfilled and protected.(Benuf, 2018)

The I Made Same case illustrates that in the formulation of law to protect intellectual works, it does not necessarily mean that there is a place for people who are the target of protection for those concerned because there are different perceptions. The development that exists in society is a debate between the needs of society economically and the attitude of respecting copyright. The problem of weak law enforcement is due to the ability of law enforcers to understand copyright provisions. So that the benefits of the Copyright Law can not be fully enjoyed by the community.

One example of the regulations in the field of economics is property rights to an intellectual (IPR). (Santoso, 2012). IPR is a law that contains economic and business values, IPR is a daily problem. Intellectual Property Rights is a right that arises as a result of human intellectual abilities in various fields that produce a process or product that is beneficial to mankind. Works in the fields of science, literary arts, and inventions in the field of technology are examples of creative works of human intellectual creativity, through their creations, tastes, and works. These copyright works give rise to military rights for the creator or inventor. (Santoso, 2012). It is important to distinguish such works from other forms that can also be owned as property by humans, but do not grow or are produced by human intellectual creativity, for example property rights obtained from nature (land, plants) and other material rights that are passed on. In the legal system in Indonesia, the Intellectual Property Rights entered as private property rights that are intangible (intangible) (Kesowo, 1992). Law is always developing, following the movements of the times and these two things are indeed impossible to avoid. Changes in-laws can be used as an indication that an era has ended or a new era has emerged. F. Sugeng Istanto in Abdul Latif stated that the process of change ius constitutum be ius constituendum due to changes in the life of the 


\section{Juridical Analysis of the Development of Copyright Law in Relation to Legal Purposes}

community is talking about a series of events that changed the ius constitutum due to the fact that different with elements of ius constitutum to then set ius constituendum that the elements meet the realities of life in these different communities (Istanto, 2011).

In this regard, the Copyright Law is one of the laws that is undergoing development. It is known that the law of copyright has been amended many times even within parentheses less than twenty years of legislation in question had been changed four times. Budi Santoso divides copyright arrangements into two periods, namely: (Santoso, 2012)

1. colonial period: ( Auteurswet 1912)

2. period after independence:

a. Auteurswet 1912 is still in effect (Art. II transitional rules of the 1945 Constitution);

b. never made the Draft Law of Copyright in 1958;

c. Definition Act Act Copyright year 1966;

d. Definition Act Act Copyright t ear 1972;

e. Law No. 6 of 1982 on Copyright

f. Law No. 7 Year 1987 regarding changes to Law No. 6 of 1982 on copyright

g. Law No. 12 of 1997 on changes to Law No. 6 of 1982 as as amended by Law No. 7 of 1987 concerning copyright;

h. Law No. 19 of 2002 on copyright stating revoke Law long on copyright;

Noting and disk usi right that the purpose of the law is justice, legal certainty and expediency lead us to desire to how Law Act Copyrightable to realize the objectives of the law. Based on the description above, the author would like to examine more deeply about the laws that contain Intellectual Property Rights in Indonesia from a sociological perspective in a paper with the title: "Juridical Analysis Of The Development Of Copyright Laws about Legal Purposes" To limit the scope of this research, the author raises the formulation of the problem as follows, How is the development of copyright about one of the objectives of the law, namely justice? How is the development of Copyright about one of the legal objectives, namely legal certainty? How is the development of Copyright about one of the legal objectives, namely benefit?

\section{METHODOLOGY}

This paper is included in the type of normative legal research which provides prescriptive regarding the juridical analysis of the development of copyright law about legal objectives. The technique of collecting legal materials is carried out by literature study to collect legal material by reading the laws and regulations, official documents and literature related to the problem the author is researching. The legal material analysis technique is done qualitatively.

\section{RESULTS AND DISCUSSION}

\section{The Form of Justice in the Copyright Law}

In 1987, Government of Indonesia to change the Law of Copyright Year 1982 to put forward four basic wishful law contained in mukadimahnya:

1. The provision of legal protection for copyright is intended as an effort to create a better climate for the growth and development of a passion for creativity in the fields of science, art and literature;

2. While increasing national development activities, particularly in the fields of science, art and literature, copyright infringement has also developed, especially in the form of piracy;

3. The copyright infringement has reached a dangerous level and can damage the life of the people in general and the interest in creating in particular;

4. To resolve and stop copyright infringement, it is deemed necessary to amend and improve several provisions in Law Number 6 of 1982 concerning Copyright:

The enactment of the 1997 Copyright Law as the Copyright Law in lieu of the 1987 Copyright Law, uses three legal considerations which are at the same time the objectives of its enactment which are quoted as follows:

1. Provision of more effective legal protection for Intellectual Property Rights, especially in the field of copyright, needs to be further improved in order to create a better climate for the growth and development of the spirit of creation in the fields of science, art and literature, which is very much needed in the implementation of national development aimed at the creation of a just, prosperous, advanced and independent Indonesian society based on Pancasila and the 1945 Constitution.

2. Carry out the obligation to adjust national laws and regulations in the field of Intellectual Property Rights including copyrights to TRIPs.

3. Amend and improve several provisions of Law Number 6 of 1862 concerning Copyright as amended by Law Number 7 of 1987 by law.

Legal considerations Act Copyright 1997 compared with the legal reasoning used to change the Law of Copyright 1982, there are some differences which is quite striking that the Act Copyright 1987 the emphasis is more focused on aspects of copyright protection 


\section{Juridical Analysis of the Development of Copyright Law in Relation to Legal Purposes}

against copyright infringement which is deemed to have reached a dangerous level and can damage the life of the community in general and the minimum to create in particular.

The author argues that the process of developing copyright protection in Indonesia goes through two processes, namely by voluntary and then by coercion with the following description:

1. By voluntary means (voluntary)

The process of the development of voluntary, there is the development of the Law of Copyright in the period Auteurswet 1912 Copyright Act No. 7 of 1987. Over the past 70 years, Auteuret 1912 void under Statute 1912 No. 600 who contested tukan by the colonial government. In 1958, the decision of the Cabinet of Prime Minister Ir. Juanda, that Indonesia does not participate as a member of the Bern agreement for the Protection of Literary and Art Works. On January 9, 1965, a Copyright Bill drafting committee was formed which succeeded in compiling the Copyright Law Draft consisting of 40 articles. Then, in 1982 the new laws of copyright (Noerhati, 1997).

To provide protection for creators of literary and artistic works, the Indonesian government was promulgated the 1982 Copyright Law. Then the 1982 Copyright Law underwent a development by making changes to the 1987 Copyright Law. Changes to the law in a relatively fast period were motivated by the following two things:

a. Granting legal protection of copyright is essentially dimaksudka $\mathrm{n}$ an effort to mewujudk 's a better climate for the growth and development of creative passion in science, art and literature;

b. In the midst of increasing national development activities, particularly in the fields of science, art and literature, copyright infringement has also developed, especially in the form of piracy;

Thus, it is clear that changes of Act Copyright 1982 to 1987 carried out by the voluntary (voluntary), the existence of a need to provide protection to the creators or local artists Indonesia that Indonesian culture to grow and have a positive climate. In addition, in the 1982 period there were copyright infringements. In this change, what is interesting to note is the increased recognition of creativity as a personal right, social functions are recognized, but the authority of the state is also limited, in addition to the recognition of foreign copyright which now has a place. This shift in attitude is a shift from state ethics to human rights ethics which should be highly respected, because human awareness as a normative will is supported (Noerhati, 1997).

2. By force (forcing / coercion).

The author argues that after the period of the 1987 Copyright Law, the development of copyright law protection in Indonesia was carried out by force. The author is of this opinion on the grounds that since the 1987 Copyright Law, namely Law Number 12 Year 1997 was colored by foreign influence in the form of the General Agreement on Tariff and Trade (GATT 1994) where one of the aspects is TRIPs (Trade Related Aspect of Intellectual Property Rights). Juridical implications for Indonesia as a member of WTO, then Indonesia must adopt TRIPS d natural laws of its national. According to the Agreement regarding Trade Related Aspects of Intellectual Property Rights, including trade in counterfeit goods attached to the master agreement regarding the WTO, each member of the WTO is required to in their national domestic law also contain provisions that provide protection to aspects of IPR (Intellectual Property Rights), this includes the trade in counterfeit goods (including Trade in Counterfeit Goods). At least or at least the members of the WTO must provide in this domestic law the same protection as stated in the TRIPS. However, they are not required to "exceed" in providing the protection in question. And members are also considered free to determine for themselves the most appropriate way to incorporate the provisions of this TRIPS into their legal system and legal practice.

With the enactment of Law No. 6 in 1982 on H ak C i pta later amended by Law No. 7 in 1987 and U ndang- U ndang No. 12 year 1997 until the enactment of copyright law latest U ndang- U ndang No. 19 of 2002, which became effective on 23 July 2003 , it has been unable to provide adequate protection to the works of copyright, particularly piece of music. This can be seen from the high rate of piracy of music in the form of cassettes, CDs and VCDs in Indonesia in 2001 reaching 600 percent and in 2002 it increased sharply to 1000 percent with total losses for the recording industry of around 11 trillion rupiah. In 2003 it reached $90 \%$ with total losses of more than 14 trillion rupiah (Keadilan, 2003).

Based on the utilitarian theory, the state must adopt several policies (for example, making laws and regulations) that can maximize the existence of its members. However, the utilitarian theory allows exceptions to copyright protection in the public interest. It is shown that there are several exceptions in copyright which have colored the development of copyright law, such as the use of works for educational, research purposes etc. In addition to the rights owned by creators and copyright holders under Article 2 and Article 3 of Law No. 12 Year 1997 concerning Copyrights, there is a right which is called economic rights (Economic Rights) that the rights owned by the creator or copyright holder to benefit economy of creation which consists of the right to:

1. Producing works of all kinds

2. Circulating reproduction of works to the public

3. Rent out reproductions of works

4. Make translations or adaptations 


\section{Juridical Analysis of the Development of Copyright Law in Relation to Legal Purposes}

5. Announcing works to the public

Enforcement of the Copyright Law must prioritize the principle that this law is really made to provide universal justice, thus with regard to copyright protection, everyone in this country is no longer allowed to measure the sense of justice based on their own subjective perspective. . Everyone is not allowed to think that what is fair is what benefits him, without the need to understand the rights associated with protecting the creations of others. Thus, it is necessary to instill an awareness that piracy of a copyrighted work is a criminal act and just like any other crime, piracy of a copyrighted work will be subject to strict and real sanctions. Changing this vision requires process and time, and is a challenge for the government and all parties concerned to make it happen. Furthermore, it must be fully realized that the birth of the Copyright Law is not solely for implementing the TRIPs-WTO agreement, but is further aimed at achieving order and justice in the field of copyright. Thus, international interests and national interests must always go hand in hand, even in many cases priorities must prioritize national interests first. As a good law, a legal product such as law in its enforcement must adhere to the principle that the law must optimally provide a sense of justice and peace to the community through a well-maintained climate of order, as well as the Copyright Law.

\section{LEGAL EXPRESSION IN COPYRIGHT LAW}

Basically, the changes made Law about copyright years 1997 against copyright provisions by Law about copyright years 1987 includes two kinds of furnishing and addition of each breakdown as follows:

1. Some improvements:

a. Definition of creation

By the Law about copyright years 1997 Article 1 paragraph 2: Creation is the result of any work of creators in a distinctive form and show originality in the field of science, art and literature. The definition of this creation is a refinement of the definition contained in the Law about copyright years 1987.

Improvements is intended to further confirm that a creature which for example is a book for copyright protection needs to meet the following elements:

1) In a distinctive form, which means that the published book has been completed so that it can be seen or read.

2) Shows authenticity, which means that the book published is a work in the field of science, or art or literature that results from the writer's personal ability and creativity

b. Protection of an unknown creation Changes made Law about copyright years 1997 against Law about copyright years 1987 in the form of refinement Law about copyright by completing the Law about copyright years 1987 Article 10A with words for the benefit of its creator. This improvement is intended to confirm the status of copyright in the case where the work is not known by the creator and is not or has not been published, just as the creation is appropriate.

c. Protection period In Law about copyright years 1987, Article 26 does not set the creations of translations, interpretations, adaptations, anthologies and other works from the adaptations that protection during the life of the author and continue until 50 years after the creator's death.

d. Exceptions for copyright infringement Based on the Law about copyright years 1997, Section 14 (a) stipulated that provided the source is to be called, the following shall not be considered a violation of copyright, namely the use of another party's creation for educational purposes, research, scientific writing, preparation of reports, writing criticism and reviewing a problem provided that it does not harm the reasonable interests of the creator (Article 14 letter (a))

e. Rights and authority to sue Law about copyright years 1997 Article 42, when compared to the same article in the U ndang- U ndang $\mathrm{H}$ ak C ipta 1987, set more firmly defend the rights and the authority to sue to protect the economic interests of creators and identifies the role holder copyright and the role of district courts.

In substantive, there are 10 provisions of the new in the list in the Law Number 19 Year 2002 on Copyright. Tenth provisions of these are as follows: (Utomo, 2010)

1. The database is a protected work;

2. The use of tools of any kind via cable or without cable, including Internet media, for screening products discs optic (optical disc) through audio media, audio-visual media and / or means of telecommunications.

3. Settlement of disputes by Pengadilan Niaga, arbitration or alternative settlement of disputes.

4. Determination while the courts to prevent the loss of more substantial for holders of rights;

5. The deadline for processing civil cases in the field of copyright and related rights, both at the Commercial Court and the Supreme Court;

6. Inclusion of electronic management information rights and technology control tools;

7. Inclusion of monitoring and protection mechanisms for products using high - tech production facilities;

8. Criminal threats for violations of related rights;

9. The threat of punishment and fines minimal;

10. The threat of punishment against the propagation of the use of computer programs for the benefit of the commercial is not legitimate and against the law. 


\section{Juridical Analysis of the Development of Copyright Law in Relation to Legal Purposes}

Apart from the development process $\mathrm{U}$ ndang- $\mathrm{U}$ ndang $\mathrm{H}$ ak $\mathrm{C}$ ipta both sukrela or coercion, we need to realize that Indonesia has acknowledged the same time trying to provide optimal protection against a work and to the creators to get right its economic and moral rights. Roscue Pound held three main categories of interests protected by law, namely: (Soetiksno, 2008)
1. public interests
2. social interests
3. private interest

In terms of foreign intervention, it is the result of the current globalization that is sweeping the world today, where changes in the value system in people's lives cause various problems so that it needs to be regulated by legal rules as law making and requires law enforcement as law enforcement. This is important to implement because changes in values will continue to occur and is a reality that cannot be ignored (Manan, 2009). The politics of law regarding copyrights, patents and trademarks cannot be separated from the interests of these rights which are owned by foreigners. The laws and regulations of any country are always made by humans with a basic thought (mindset) in their minds. This basic thinking can be influenced by many factors such as ideological or religious beliefs, experiences, or knowledge as well as interests. These interests can also be of various kinds (personal interest, group or party interest, people's interest or foreign interest).

Of all the factors above, the most dangerous is when foreign interests dominate. Although the interests of the people at large may be wrong or contrary to certain beliefs (ideology and religion), at least the real effect will only be felt in the long term when the people of the developed countries in the West realize it. However, if foreign interests are dominant, then it can be guessed that in a short period of time these laws and regulations have caused widespread disasters for society. In the framework of legal reform thinking that occurs in Indonesia, Solly Lubis mentions that there are two views that influence each other, namely first: changes made dogmatically, namely changes that are carried out as a whole and their implementation is carried out very carefully with very in-depth research by involving all related elements and communities that accept change. This group tends to maintain moral and cultural values in the framework of fostering National law, second: changes that are empirical in nature, namely changes that are implemented by first making laws or other regulations that are considered important and urgent according to needs (Lubis, 2002).

In line with the aforementioned matters, in relation to the changes implemented in Indonesia, Satjipto Rahardjo argued that the application of legal changes should be distinguished between legal development and the activity of changing an existing law. Therefore, the legal amendment activities that are being carried out in Indonesia have their own characteristics and are independent (stand alone). Changes in law are not solely carried out because the law is felt to be inadequate to regulate people's lives, but Indonesian society itself has now undergone changes and these changes are fundamental in nature which have the aim of creating a new Indonesian society in accordance with the laws that live in it society (Rahardjo, 1981). Lawrence M. Friedman argues that in relation to legal changes, these changes can occur in three elements that are very dominant in the law, namely, first: the legal structure is a pattern that shows how the law is carried out according to its formal provisions. This structure shows how courts, lawmakers and other legal entities run and are run, second: the substance of the law is the rules that are used by legal actors when carrying out their actions and legal relations, third: legal culture. Regarding this matter, it comes from the people or users of legal services such as the court and if the community chooses the court to resolve the case that occurs, the community will have a positive perception of the Court. Community culture is very important in the context of legal reform and community reform (Friedman, 1975). All of these still have their respective parts, because a system without the components in it will become redundant (Salman \& Sutanto, 2004). Besides that, the change in law should be directed at the creation of a legal system that allows the people's basic rights to be respected, fulfilled and protected.

\section{INTENTION OF BENEFITS IN COPYRIGHT LAW}

Regarding the Copyright Law, there is an interesting research result conducted by I Ketut Wirawan regarding Legal Culture and the Function of the Copyright Law: The Case of the Balinese Artist Community. This research regarding the views of the Balinese artist community towards monopoly and the imitation of copyright works that are given to the creator by the Copyright Law does not have the proper place among Balinese artists. Researchers have come to the conclusion that the basic cultural values of Balinese indigenous peoples still provide a place for the practice of imitating copyrighted works. Providing an opportunity to imitate a copyrighted work is seen as providing employment opportunities for other parties. Working (doing karma) in the Balinese customary law community is a necessity that must be done in living life as a human being. Work is also fulfilling karma (lust / desire) which is a human instinct in life.

Of the 20 statues he has made, one of I Made Same's works was registered with the Directorate General of IPR in 1993, and a copyright certificate has been obtained. Dip erolehnya copyright certificate is a separate award for I Made Same above the crowd poured in the form of sculpture art with its own uniqueness. Currently, the success of I Made Same has inspired many other sculptors to create the same model, even a sculptor near where I Made Same has made such a statue, but until now he has not made any demands or complaints against this imitation. I Made Same is of the opinion that other people also have the right to earn a living by making sculptures as he does. Occasion, $\mathrm{n}$ menitu that I a given considers the placement of Karma Yoga teachings and Chess Purusharta, where he has given the opportunity for others to work meet his living by providing opportunities imitate his work. He 


\section{Juridical Analysis of the Development of Copyright Law in Relation to Legal Purposes}

also understands the right of all people to fulfill their daily needs (ama) through the search for artha, even though it is done by imitating it, as long as it is still within the circle of dharma (religion). Even if in the society only he himself could earn it will cause an imbalance in the environment, which will lead to jealousy and unfair competition, which ultimately lead to lack of stalled peace $\mathrm{n}$ that will be difficult for him (Wirawan, 2000).

Based on the description above, it can be illustrated that in the formation of a law with the aim of providing protection for intellectual works, it does not necessarily mean that there is a place for people who are the target of protection for those concerned because there are differences in perceptions between the artists in Bali and the government, especially the legislature who authority to form laws.

When viewed in terms of legal development compared to community development, law can be differentiated as follows:
1. Social Engineering Law
2. Progressive Laws
3. Slow Motion Law
4. Stagnant Law

The movements of the four legal models function and develop differently, with different consequences as seen in the movement of the four legal models function and develop differently, with different consequences as shown in the following table this:

Table 1. Table of Functions, Development and Consequences of four legal models

\begin{tabular}{|l|l|l|l|}
\hline Type of Law & $\begin{array}{l}\text { Development } \\
\text { Public }\end{array}$ & $\begin{array}{l}\text { Development } \\
\text { Law }\end{array}$ & Consequences \\
\hline $\begin{array}{l}\text { Social Law } \\
\text { Engineering }\end{array}$ & Up & More advanced & Engineering society \\
\hline Progressive Law & Up & Up & Development \\
\hline $\begin{array}{l}\text { Slow's Law } \\
\text { Motion }\end{array}$ & Up & Less advanced & $\begin{array}{l}\text { Maintaining pattern / } \\
\text { stability }\end{array}$ \\
\hline Stagnant Law & Up & Not going forward & $\begin{array}{l}\text { Anarchy / turmoil / } \\
\text { reform }\end{array}$ \\
\hline Stagnant Law & Highly advanced & Very not advanced & Social Revolution \\
\hline Stagnant Law & Not going forward & Not going forward & $\begin{array}{l}\text { Isolated / uncivilized } \\
\text { society }\end{array}$ \\
\hline
\end{tabular}

If the views seen in terms of legal changes with changes in society, the development of the Copyright Act which is characterized by the formation of IPR legislation is a proactive change. In this case, the community has not yet practiced these changes, but there are already developing ideas about the changes in question. Then, before the community practices the changes referred to, the law has been changed first, so as to accelerate changes in community practices. In this case, the phrase "law as a means of engineering society" applies (law as a tool of social engineering).

The view that law is not just passive waiting for change, but active in creating change, where the role of law in development is to establish infrastructure for achieving political change, economic change and social change in society. Undang OF Copyrights are in formation in addition to overshadow the background by the Ratification of the TRIPS Agreement has the aim to provide protection to the works of creation consisting of arts, science and culture to create a climate conducive to creating a masterpiece for example such as music, painting, software that able to boost the national economy. In terms of realizing these goals, it is the society that needs to be changed. The public must be engineered so that they behave in accordance with what is expected from the Copyright Law, for example, is the reduction of community behavior in violating the provisions of the Copyright Law, such as pirating CD / VCD for copyright, selling pirated CD / VCD in several places. To carry out these social changes, the Copyright Law is equipped with sanctions to create a threat and deterrent effect. And these sanctions are of course directed not only to the perpetrator of copyright infringement but also to any person or entity who enjoys the results of such copyright infringement, for example as a person who participates in selling (distributes).

Law of Copyright as an engineer social for inventors, creators, inventors characterized the filing of petitions to the DirectorateGeneral H ak K ekayaan I ntelektual to obtain or recognized the right to work of intellectual though Act Copyright does not oblige to the request. Based data statistic Direktorat Jendral Hak Kekayaan Intelektual: 


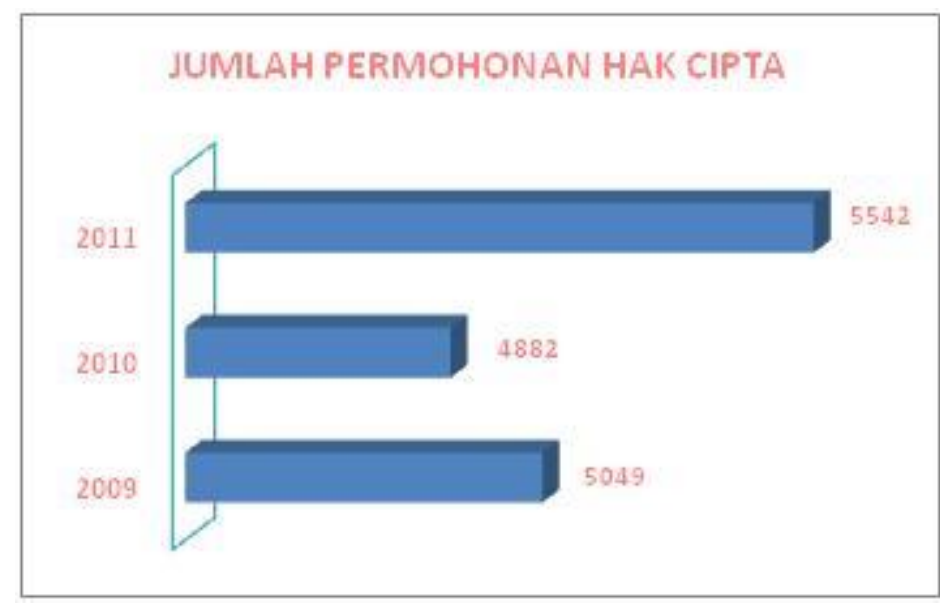

Figure 1. Data Statistic Total Request Copyright Directorate Jendral Hak Kekayaan Intelektual Source: http://www.dgip.go.id/statistik-hak-cipta

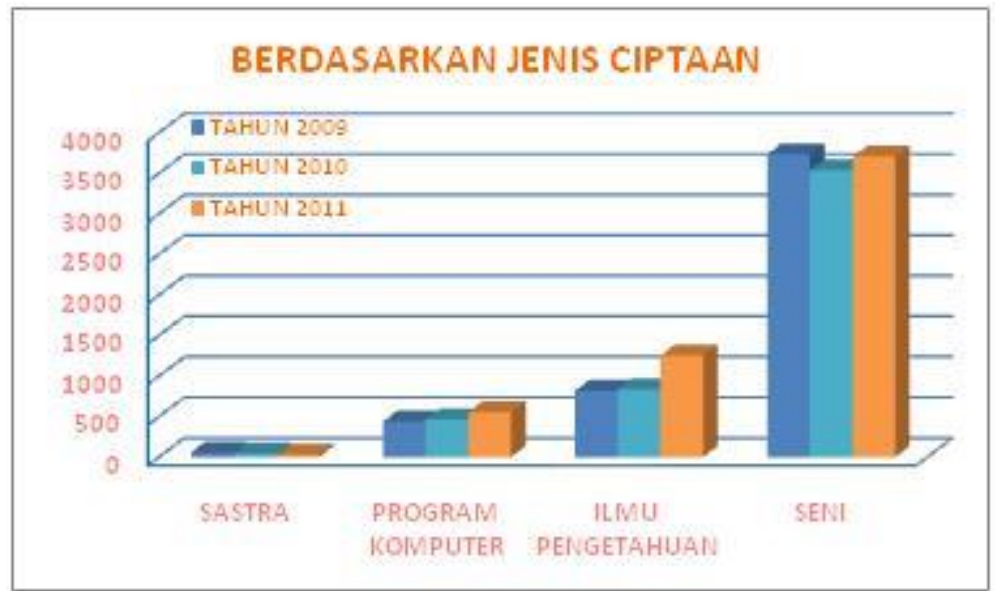

Source: http://www.dgip.go.id/statistik-hak-cipta

Social engineering Rights Act reserved to the general public, authors argue has not shown signs that lead to what is desired by the Copyright Act. In the development of copyright law in Indonesia from Auteurswet 1928 to U ndang- U ndang Copyright most recently, the author get a fact in the form of data, that during the change per change U ndang- U ndang Copyright, is not followed by obedience masyarat against copyright In other words, in every amendment there are always copyright violations, both local and foreign works.

Se has Copyright Law No. 19 Year 2002 was enacted, as many as 192 cases of infringement of intellectual property rights occurred in the period from July to December 2008. Of the 112 cases of violation of intellectual handled by the police, 106 cases related to infringement of copyright, three cases in the field of brand, and three cases in the area of industrial design rights (VIVA, 2009). The description above is able to illustrate the disobedience of the Indonesian people to every Copyright Law that has ever been in effect, especially from UUHC Number 6 of 1982 to Copyright Law Number 19 of 2002. Based on data held by the National Police Headquarters, there are 251 cases. Related to copyright infringement that was discovered by the authorities in 2004 , while in 2005 and 2006 it jumped to 423 and 1439 cases. This made Indonesia included in the USTR (United States Trade Representative) priority watch list from 2001 to 2006. Throughout 2019, the Ministry of Law and Human Rights noted that trademark violations were the most complained of. The number of complaints submitted to the Directorate General of Intellectual Property (DJKI) of the Ministry of Law and Human Rights was trademark infringement (34 complaints), followed by complaints of copyright infringement ( 7 complaints), patents (2 complaints), and industrial designs (4 complaints) (CNN INDONESIA, 2020).

Based on the data that the author has presented above, the behavior of the Indonesian people towards works shows the category of lawless behavior. In other words, the role of the Intellectual Property Rights Law as a means of social engineering that should be able to manipulate people who do not comply with the law towards law-abiding people in the field of IPR is not optimal. B erdasarkan observation Writer, goods worth allegedly produced by ignoring the Law of Copyright prevalent in the community. For example, in several places, including public and open places, there are stalls selling pirated CDs / VCDs. Duplication of pirated optical discs is still the belle of offenders. Optical disc violations account for up to 90 percent of copyright infringements. 


\section{Juridical Analysis of the Development of Copyright Law in Relation to Legal Purposes}

In order to be able to carry out a holistic study of law and social reality, an empirical approach is needed that allows observing the operation of the law. In this case the law must be seen as a system consisting of three components, namely the substance of the law (rules and norms), the legal structure (institutions or law enforcers) and legal culture (ideas, attitudes, beliefs, hopes, and views on law). Legal substance laws of copyright, author assess've been nice to oversee the protection of copyright, in terms of the scope of copyright protection, the type of crime that is a regular offense (not a complaint) sanctions, existence. The structure in the sense of law enforcement officers that the author highlights is law enforcement officers, especially the police. With regard to ordinary offenses (not complaints), the police should be the morning entrance to enforce copyright infringement in the field. But in reality, the field is still a seller's stalls of pirated VCDs were so many, in several Indonesian cities still are stalls selling pirated books or not the original bought and traded freely. In essence, copyright law 19/2002 has imposed sanctions on people who pirate, distribute and sell pirated goods.

In terms of legal culture, although the Law of Copyright has changed from year to year 5 times accompanied by sanctions is augmented and diperlkuas scope, it is not to scare the people of Indonesia to remain in violation of a work of creation such as piracy CDs, VCDs, DVDs, download songs or movies on the Internet. According to the author's opinion, this is inseparable from the habits of most Indonesians who like to imitate or imitate, like to think practically and economically. So Copyright law The authors say failed to become a means of control and means engineers social. Even in the extreme, specifically to the development of the Copyright Law, the public was being left behind by the law. Indonesian society is not ready by the presence of $U$ ndang- $U$ ndang Copyright though the description of the previously mentioned that one of the development process copyright law is by voluntary / voluntary.

\section{CONCLUSION}

Based on the results of the research, it is known that, the purpose of law is as a tool for social engineering, so that the Intellectual Property Rights Law is also a social engineering tool aimed at making law-abiding society towards law-abiding society in the field of IPR is not optimal. The development of the Copyright Law in relation to legal objectives can be seen from the substance of the law, the copyright law is good at guarding copyright protection, in terms of the scope of copyright protection, the types of crimes that are ordinary offenses (not complaints) of sanctions, existence. Judging from the legal structure, in this case law enforcement officers, especially the police. Where cases of copyright infringement in Indonesia are ordinary offenses, it should be a morning entry point for police officers to enforce copyright infringements in the field. However, in reality, there are still many stalls selling pirated VCDs. In terms of legal culture, although the Law of Copyright has changed from year to year 5 times accompanied by sanctions is augmented and diperlkuas scope, it is not to scare the people of Indonesia to remain in violation of a work of creation such as piracy CDs, VCDs, DVDs, download songs or movies on the Internet. This is inseparable from the habits of most Indonesians who like to imitate or imitate, like to think practically and economically. So the Author's Copyright Law says it failed to become a means of control and a means of social engineering. Even in the extreme, especially regarding the development of this Copyright Law, it is the people who are left behind by the law. The Indonesian people have not been able to implement the Copyright Law, this has made the Copyright Law far deviated from its legal purpose, namely as a tool for social engineering.

\section{REFERENCES}

1) CNN INDONESIA. (2020, Januari 1). Pelanggaran Merk Paling Banyak Diadukan Ke Kemenkumham. Retrieved from Pelanggaran Merk Paling Banyak Diadukan Ke Kemenkumham: https://www.cnnindonesia.com/teknologi/20191231141341-185-461331/pelanggaran-merek-paling-banyak-diadukan-kekemenkumham

2) Friedman, L. M. (1975). The Legal System: A Social Science Perspective. New York: Russel Sage Foundation.

3) Istanto, S. (2011). Politik Hukum (Bahan Kuliah). In A. Latif, Politik Hukum. Jakarta: Sinar Grafika.

4) Keadilan, F. (2003, 10). Sekali Lagi Melawan Pembajak. 10, p. 13.

5) Kesowo, B. (1992, Februari 4). Kebijakan Di Bidang Hak Milik Intelektual Dalam Hubungannya Dengan Dunia Perdagangan Internasional Khususnya GATT. Panel Diskusi Bidang Hukum Hak Milik. Jakarta, DKI Jakarta, Indonesia: DPP Golkar.

6) Benuf, K. (2018). Politik Hukum Legislator dan Ideologi Pancasila. Gema Keadilan.

7) Lubis, S. (2002). Sistem Nasional. Bandung: Mandar Maju.

8) Manan, A. (2009). Aspek-Aspek Pengubah Hukum. Jakarta: Kencana Prenada Media.

9) Noerhati, T. H. (1997). Urgensi Kebudayaan Sebagai Materi Hukum Nasional. dalam "Identitas Hukum Nasional. Yogyakarta: Fakultas Hukum UII.

10) Rahardjo, S. (1981). Pembaharuan Hukum Perdata untuk Pembangunan Masyarakat. Simposium Pembaharuan Hukum Perdata Nasional (p. 1). Yogyakarta: BPHN.

11) Salman, O., \& Sutanto, A. F. (2004). Teori Hukum (Mengingat, Mengumpulkan dan Membuka Kembali). Bandung: Refika Aditama. 


\section{Juridical Analysis of the Development of Copyright Law in Relation to Legal Purposes}

12) Santoso, B. (2012). HKI (Hak Kekayaan Intelektual). Semarang: Pustaka.

13) Soetiksno. (2008). Filsafat Hukum (Bagian II). Bandung: Pradnya Paramita.

14) Utomo, T. S. (2010). Hak Kekayaan Intelektual (HKI) di Era Global. Yogyakarta: Graha Ilmu.

15) VIVA. (2009, Mei 1). VIVA NEWS. Retrieved from Indonesia Masuk Daftar Hitam AS: http://life.viva.co.id/news/read/53933-indonesia_masuk_daftar_hitam_as

16) Wirawan, I. K. (2000). Budaya Hukum Dan Disfungsi Undang-Undang Hak Cipta: Kasus Masyarakat Seniman Bali. Tesis. Semarang: Magister Ilmu Hukum UNDIP. 